\title{
Assessing Toxic Elemental Concentrations in Marine Fish Trachurus capensis (Cape Horse Mackerel) and Implications for Public Health
}

\author{
Sanjeev Debipersadh, Ramganesh Selvarajan*, Timothy Sibanda, Richard Naidoo \\ Department of Environmental Sciences, UNISA Florida Campus, P.O Box 1710, Florida, South Africa
}

Received: 23 March 2017

Accepted: 18 July 2017

\begin{abstract}
While fish is considered a healthy component of the human diet, consumption of fish with high levels of trace metals in their flesh constitutes a public health risk as trace metals have been proven to be toxic. We investigated the concentrations of toxic elements in seawater and also in different body parts of the fish Trachurus capensis caught near Durban, South Africa, using inductively coupled plasma-atomic emission spectrometry (ICP-AES). The highest metal concentration in fish body parts was observed for $\mathrm{Pb}$, followed by $\mathrm{Zn}$. Significantly higher levels of Mn were observed in fish gills as compared to the tissue (muscle) and fish frame. With respect to bioaccumulation, significantly higher $\mathrm{Pb}$ levels were observed in fish tissues compared to $\mathrm{As}, \mathrm{Cr}$, and $\mathrm{Mn}$. In the frame, significantly higher Pb levels were observed compared to all other metals except Ba. There were no significant differences in the concentrations of different metals in fish gills. Overall, the toxic metal concentrations in the muscle of cape horse mackerel were below levels of concern for human consumption as defined by the FAO and WHO.
\end{abstract}

Keywords: Trachurus capensis, public health, toxic metals, bioaccumulation

\section{Introduction}

Contrary to the historical belief that the ocean is immune to pollution due to its vastness, anthropogenic activity has made oceans susceptible to pollution [1]. Commercial wastes from industries are considered the major potential source of pollutants finding their way into the sea - particularly heavy metals and petroleum hydrocarbons [2]. Heavy metals can bioaccumulate to

*e-mail: ramganesh.presidency@gmail.com toxic concentrations in aquatic food webs, resulting in serious environmental and ecological consequences [3]. In the aquatic food-web, fish stand at the higher levels and may accumulate high concentrations of some toxic metals from both seawater and the food they eat [4-5].

Fish, however, is considered a healthy food in the human diet because of its high nutritional benefits related to proteins of high biological quality, attractive lipid composition, beneficial minerals, and useful vitamins [6]. Due to the lipid solubility of heavy metals and their resistance to several degenerative processes in animal tissue, different organs of fish can bioaccumulate trace metals to considerably higher concentrations than those 
found in the water around them [7]. Accumulated toxic metals from fish could easily interact with human genetic materials and other bio-macromolecules, leading to organ distortion, mutation, nervous disorder, kidney malfunctioning, bone diseases, and cancer [8]. Arsenic, cadmium, chromium, copper, lead, nickel, and zinc are the most commonly found toxic trace elements in nature, which enter water sources by natural means and through human activities such as wastewater discharge [9] and are the most likely to accumulate in fish organs. Consequently, determining heavy metal accumulation in commercial fish is an important task in order to calculate the viable risk to human health due to fish consumption [10].

Trachurus capensis is a pelagic fish species commonly called mossbunker or cape horse mackerel that forms a large population in the surface layers of the ocean (pelagic zone). They are common along the entire coast of South Africa and Namibia, with the highest population between the west coast and the Agulhas Bank. It is a common "by-catch" species that is a high source of protein and is exported to rural South Africa and other African countries. While bioaccumulation of toxic elements in edible fish tissues remains a health concern, relatively few studies have investigated the levels of metals in some fish species from the Durban coast [11-12]. The main aim of this work, therefore, was to estimate the concentration of toxic trace elements (Al, $\mathrm{As}, \mathrm{Pb}, \mathrm{Cr}, \mathrm{Mn}, \mathrm{Zn}$, and $\mathrm{Cu}$ ) in seawater and the bait fish $T$. capensis collected from selected popular fishing spots off the Durban coast, since they are an important component of the human diet in this area.

\section{Materials and Methods}

Three sites were chosen in and around the harbour of Durban, South Africa:

- Harbour mouth (S 2952.017' - E 31 ${ }^{\circ} 03.961^{\prime}$ ) immediately outside the harbour

- Container (S 2949.478' E $31^{\circ} 04.535^{\prime}$ ), situated about $5 \mathrm{~km}$ north of the harbour mouth

- Cuttings (S 2958.404' - E 3059.287'), situated about $10 \mathrm{~km}$ south of the harbour where the southern outfall waste pipes are connected to the ocean (Fig. 1)

Trachurus capensis were caught by rod and reel. Immediately after fishing, all the fish were washed with seawater and then with fresh tap water, placed on ice, and brought to the laboratory on the same day for further analysis.

The fish were dissected into three sections, namely tissue, frame, and gills. The samples were then dried at $105^{\circ} \mathrm{C}$ for $8 \mathrm{~h}$, preceded by ash drying at $650^{\circ} \mathrm{C}$ for $6 \mathrm{~h}$. Triplicate $0.5 \mathrm{~g}$ ash samples were then digested with diacid $\left(30 \mathrm{ml}\right.$ of $\mathrm{HCL}$ and $10 \mathrm{ml}$ of $\mathrm{HNO}_{3}$ in $3: 1$ ratio) on a hot plate maintained at $100^{\circ} \mathrm{C}$ until all materials were dissolved completely. Samples were then cooled at room temperature and transferred into $25 \mathrm{ml}$ volumetric flasks containing $2.5 \mathrm{ml}$ of indium (internal standard) for metal

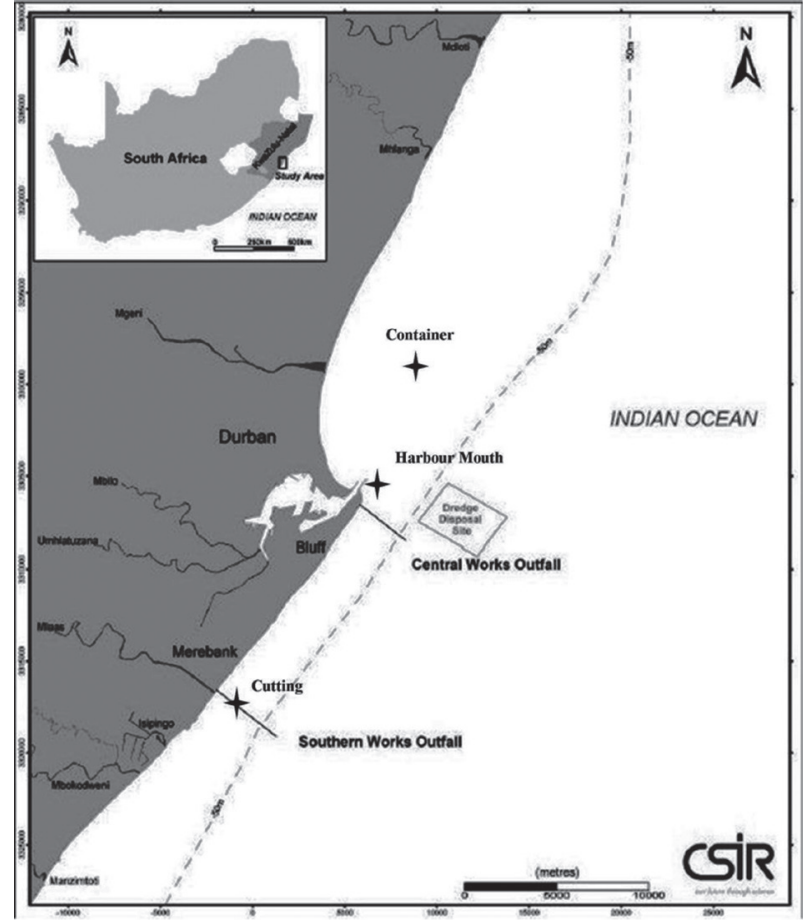

Fig. 1. Map of Durban Coast in South Africa (Sampling sites are marked) Source: CSIR, South Africa.

analysis. The samples were subjected to analysis for various trace metals using inductively coupled plasmaatomic emission spectrometry (ICP-AES).

The bioaccumulation factor (BAF) in this study was predicted using the equations of Vaseem and Banerjee [13]. The EDI was calculated by factoring in the average metal concentration in a whole fish (this study), the average daily consumption of fish by an adult person [14], the average weight of an adult African [15], and the permissible tolerable daily intake of heavy metals [16].

The statistical package for social sciences (IBM SPSS Statistics 23) was used for data analysis. Analysis of variance (ANOVA) was used to determine statistically significant differences in the concentrations of metals in water and in fish body parts at a 0.05 level of significance using the least significant difference (LSD) as the post hoc test.

\section{Results and Discussion}

The concentration of metals in seawater averaged $0.3 \mathrm{mg} / \mathrm{L}$ for all metals and in all study sites. The only slight but statistically insignificant deviation $(\mathrm{P}>0.05)$ was noted for $\mathrm{Zn}$, whose concentration in seawater was $0.38 \mathrm{mg} / \mathrm{L}$ at the site container. The average metal concentration in different fish body parts is presented in Fig. 2. This average combines values for fish caught in each of the sampling sites off the Durban coast. The highest metal concentration in all body parts assessed was observed for $\mathrm{Pb}$, followed by $\mathrm{Zn}$, while the lowest metal concentration in any body part was observed for 
Mn. Compared to other studies that evaluated metal concentrations in mackerel, higher metal concentrations were observed in our study than in previous studies (Table 1). Reported results in literature showed that metal accumulation in fish muscle varied widely depending on location [17], season [18], behavior, and feeding habits [19].

When the selective tendency of fish body parts to bioaccumulate metals was analyzed, significantly higher levels of $\mathrm{Mn}$ were observed in fish gills as compared to the tissues (muscle) $(\mathrm{P}=0.005)$ and fish frame $(P=0.008)$. The differences in the concentration of the rest of the metals in various fish body parts were not significant $(\mathrm{P}>0.05)$.

The average concentration of metals in fish tissue (muscle) in this study was far greater than the average recorded by Elnabris et al. [14] in a range of fish collected from different points of the Gaza Strip. Metals have also been shown to have varying affinities for adsorption to fish tissues mainly based on varying uptake, deposition, and excretion rates [20]. When the bioaccumulation of various metals with respect to fish body parts were compared, significantly higher $\mathrm{Pb}$ levels were observed in fish tissue compared to As $(\mathrm{P}=0.048), \mathrm{Cr}(\mathrm{P}=0.05)$, and $\mathrm{Mn}(\mathrm{P}=0.044)$. The differences in the concentrations of other metals in fish tissue were not significant. In the fish frame, significantly higher $\mathrm{Pb}$ levels were observed compared to all other metals $(\mathrm{P}<0.05)$ except $\mathrm{Ba}(\mathrm{P}>0.05)$. Other significant metal concentration differences were between As and $\mathrm{Zn}(\mathrm{P}=0.03), \mathrm{Cr}$ and $\mathrm{Zn}(\mathrm{P}=0.027), \mathrm{Cu}$ and $\mathrm{Zn}(\mathrm{P}=0.037)$, and $\mathrm{Mn}$ and $\mathrm{Zn}(\mathrm{P}=0.025)$. There were no significant differences in metal concentration in the gills. Overall, there was significantly higher $\mathrm{Pb}$ concentration in all fish body parts compared to all other metals $(\mathrm{P}=0.003)$, with the exception of $\mathrm{Zn}(\mathrm{P}=0.185)$. The calculated bioaccumulation factor for each metal confirmed these statistical assertions.
The overall average metal bioaccumulation in this study was found to be in the order of $\mathrm{Pb}>\mathrm{Zn}>\mathrm{Ba}>$ $\mathrm{Al}>\mathrm{Cu}>\mathrm{As}>\mathrm{Cr}>\mathrm{Mn}$. These findings contrast with the findings of Elnabris et al. [14], who reported higher concentrations of $\mathrm{Zn}, \mathrm{Ni}, \mathrm{Cu}$, and $\mathrm{Mn}$ as compared to $\mathrm{Pb}$, and the findings of Alam et al. [21], who reported higher concentrations of $\mathrm{Cu}, \mathrm{Cr}$, and $\mathrm{Zn}$ compared to $\mathrm{Pb}$.

Fish are an important part of a healthy diet because of their richness in omega-3 fatty acids, essential minerals, and vitamins [22]. However, because of their trophic level, fish normally bioaccumulate toxic metals - especially pelagic fish [23] - from their food, sediments, and water, as shown by the results of this study. In this regard, the negative health effects of heavy metals in fish tissue may outweigh the positive health effects of fish consumption in the long term. The estimated daily intake (EDI) of heavy metals ( $\mu \mathrm{g} /$ day/person) were calculated (Table 2 ) in order to estimate the risk of heavy metal toxicity among people who consume fish caught off the Durban coast on a regular basis.

Table 2 shows that the EDI values for $\mathrm{As}, \mathrm{Ba}, \mathrm{Cr}, \mathrm{Cu}$, $\mathrm{Pb}$, and $\mathrm{Zn}$ were within the permissible tolerable daily intake (PTDI) for an adult weighing $60.7 \mathrm{~kg}$ who consumes an average of $11.66 \mathrm{~g}$ of fish a day. Such calculations are necessary to preserve public health because the toxicity of metals is dose-dependent [24]. The value of $11.66 \mathrm{~g}$ used for EDI calculations is rather conservative as people are likely to consume more than $11.66 \mathrm{~g}$ of fish per day. The advantage, however, with using a conservative figure is that the risk is not overestimated, which may likely cause unnecessary panic among consumers and unwarranted loss of revenue for the fishing industry. However, it still remains a fact that aquatic organisms may bioabsorb toxic metals to levels that might affect even their own physiological state [20].

The EDI for As was $5.09 \mu \mathrm{g} /$ day for an adult African. The main form of As found in fish is the organic As

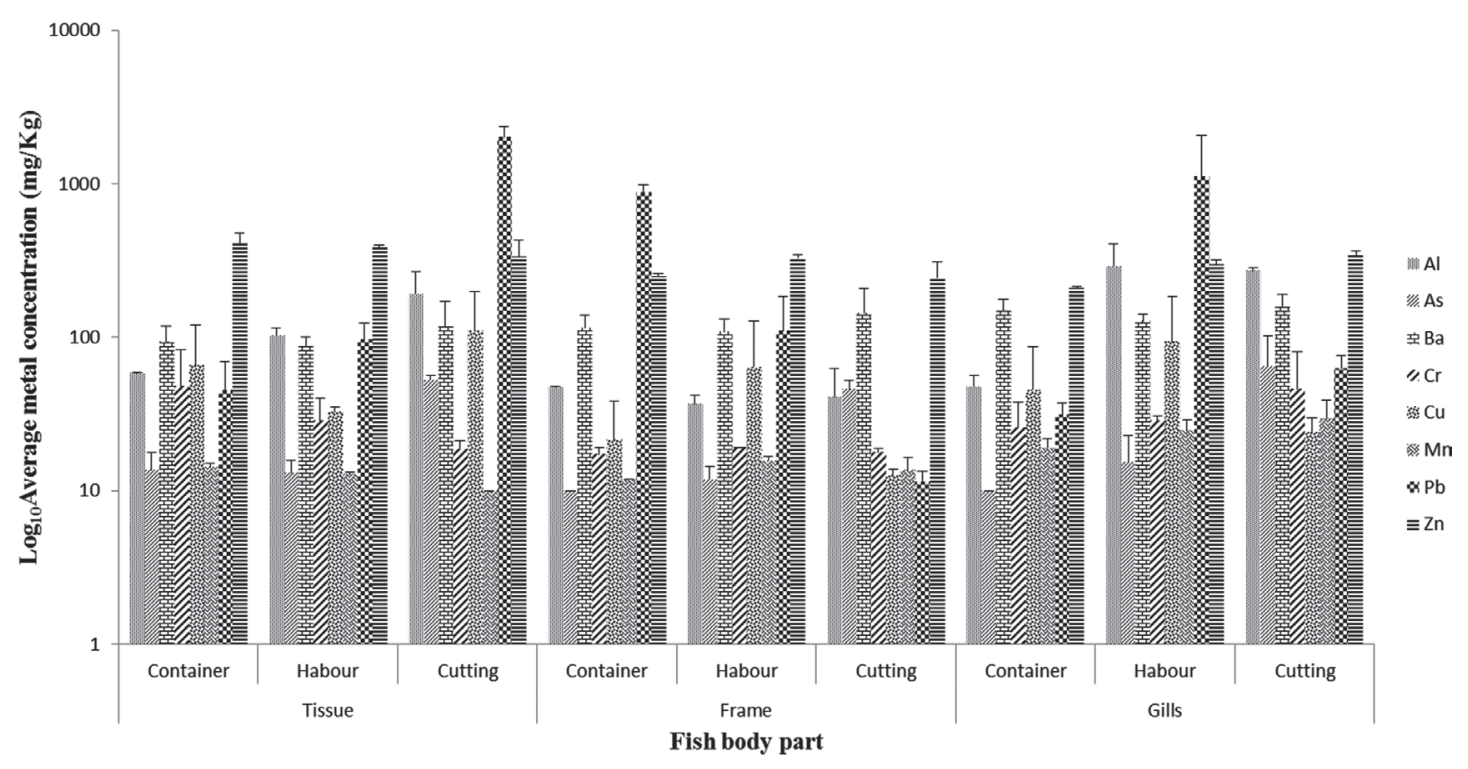

Figure 2: $\log 10$ average trace metal concentrations in different fish body parts. 


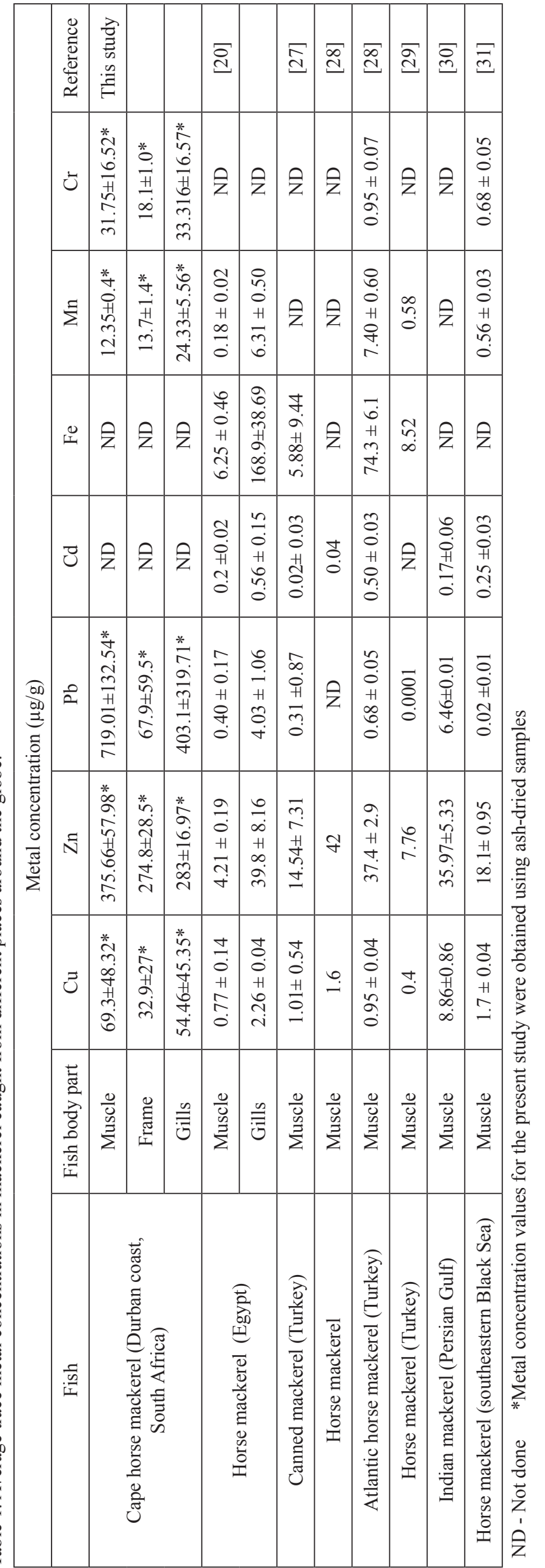

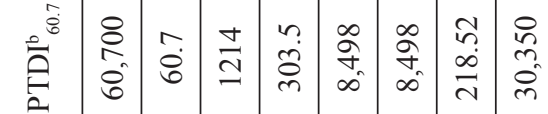

竎

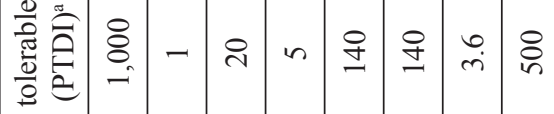

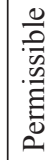

泀

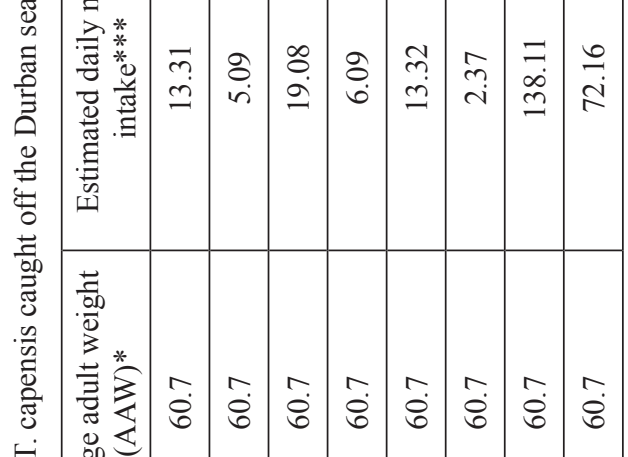

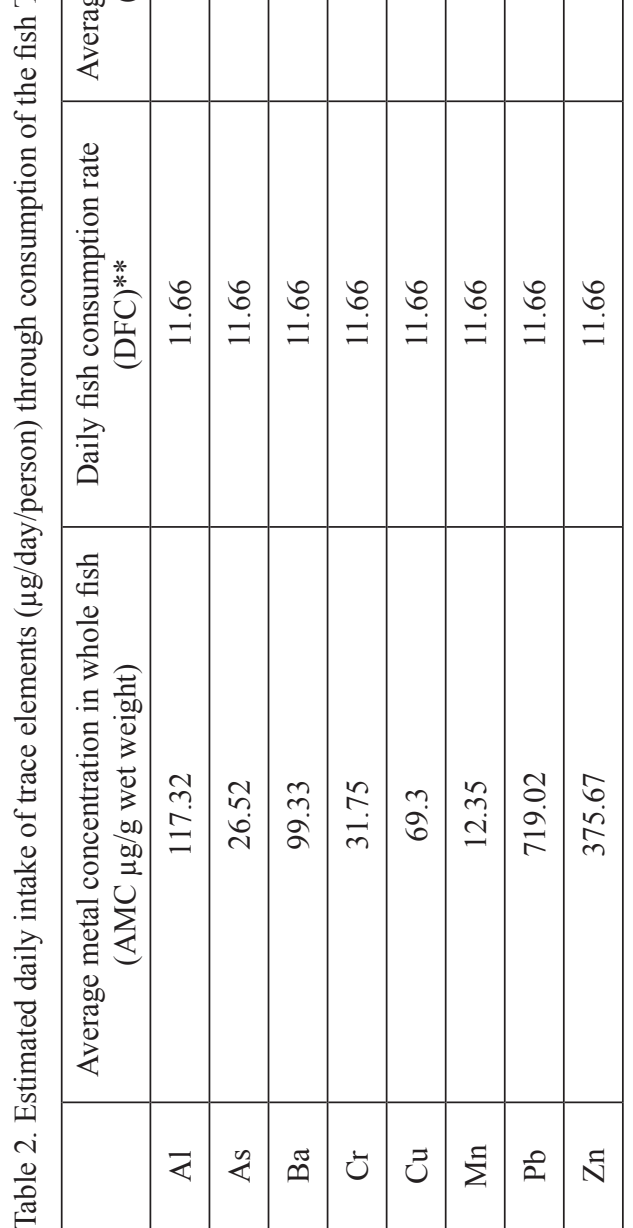

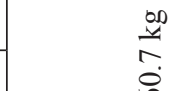

寻葛

蛋

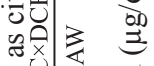

井

Uौ 完望 च

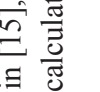

$\exists 0$. 㟢気 范艺 웅 焉惫 突 过 政 施 年罗题 
compounds such as arsenobetaine [25]. While the calculated EDI figure for As may have been lower than the permissible tolerable daily intake for a $60.7 \mathrm{~kg}$ adult African $\left(\right.$ PTDI $_{607}$ ), which is $60.7 \mu \mathrm{g} /$ day, consistent intake of low levels of As are known to cause adverse health effects, especially skin ailments [26]. If consumed in high quantities, As is known to be acutely toxic and has been linked to an array of ailments including gastrointestinal, cardiovascular and neurological disturbances [25]. Additionally, As has been reported to result in reduced growth and reproduction in both fish and invertebrate populations, and furthermore reduced migration in fish [27]. The type and severity of adverse effects are dependent on the life stages of the fish, with the juveniles more affected than adult fish. Arsenic accumulation may be higher in benthic fish than in epipelagic or photic feeders. However, humans are more sensitive to As than are aquatic organisms, which increases the risk of adverse health effects in the event that contaminated food products are consumed.

The EDI value for $\mathrm{Cr}$ was $6.05 \mu \mathrm{g} / \mathrm{day}$, and while this result may suggest insignificant effects on human health, $\mathrm{Cr}$ has been observed to variably exert toxic effects at different concentrations in different groups of aquatic organisms, with fish being more resistant compared to invertebrates, especially daphniids [28]. For $\mathrm{Cu}$, the EDI was $13.32 \mu \mathrm{g} /$ day compared to the estimated PTDI ${ }_{60.7}$ of $8,498 \mu \mathrm{g} /$ day. While $\mathrm{Cu}$ is an essential micronutrient that is involved in redox reactions, it is rapidly accumulated by plants and animals and is toxic at low concentrations in water, where early life stages of organisms appear to be more sensitive than adults to copper pollution [27].

In this study, the EDI of $\mathrm{Pb}$ as a result of fish consumption was lower than the estimated PDTI value for an adult human. However, regular consumption of fish containing trace levels of bioaccumulated $\mathrm{Pb}$ could lead to headaches, abdominal pain, and various symptoms related to the nervous system [25]. For Zn, the EDI as a result of fish consumption was lower than the $\mathrm{PDTI}_{60.7}$ value for a grown person (Table 2). Nevertheless, the bioaccumulation of $\mathrm{Zn}$ in fish muscle still poses some measure of health risk, especially to regular consumers of fish. A major difference between this study and the findings of Gorur et al. [29] and Gu et al. [30] is that metal concentrations were highest in the flesh (muscle) of the fish and lowest in the gills; however, in this study as opposed to their findings metal concentrations were highest in the gills and liver, and lowest in the muscles of all fish species tested. Our results were against expectation since usually fish are prone to metals adsorbing onto their gill surfaces while a large amount of metallothionein induction is also known to occur in fish liver [29].

\section{Conclusion}

In conclusion, trace metal pollution of both marine and freshwater resources represents an important environmental and public health concern due to their toxicity and accumulation (bioconcentration) in the food chain. Additionally, these findings point to a need for further and detailed research to determine the extent of metal bioconcentration by different dietary fish species and the extent to which this bioconcentration could be a danger to public health. We suggest that more specific recommendations regarding human consumption are done according to periodic evaluations of levels of environmental pollutants vis a vis bioaccumulation levels in dietary fish species.

\section{Acknowledgements}

The authors would like to thank Mrs. Yolanda Niharoo for her technical assistance toward metal analysis and Golden Pond Trading 67(Pty) Ltd. for providing huge support toward this study.

\section{References}

1. DEPARTMENT OF AGRICULTURE, ENVIRONMENTAL AFFAIRS AND RURAL DEPARTMENT. Kwazulu-Natal state of Environment 2004: Marine and Coastal Environment Specialist Report. Kwazulu-Natal Provincial Government, Pietermaritzburg. 2010.

2. GOMGMT B., TEZT Z. Heavy metal pollution in water, sediment and fish from from the Tigris river in Turkey. Chemosphere 29, 111, 1994.

3. GÜVEN K., ÖZBAY C., ÜNLÜ E., SATAR A. Acute Lethal Toxicity and Accumulation of Copper in Gammarus pulex (L. Amphipoda).Turkish Journal of Biology 23, 513, 1999.

4. ALLISON T.A., PAUL C.W. Histological based biomonitoring: a baseline ecotoxicological evaluation of New-Calabar River using Chrysichthys nigrodigitatus. International journal of environmental pollution research 2, 17, 2014.

5. KARADEDEA H., OYMAK S. A., UNLA E. Heavy metals in mullet, Liza abu, and catfish, Silurus triostegus, from the Atatu" rk Dam Lake (Euphrates), Turkey. Environment International 30, 183, 2004.

6. KOVEKOVDOVA L.T., SIMOKON' M.V. Heavy metals in the tissues of commercially important fish of Amurskii Bay, Sea of Japan. Russian Journal of Marine Biology 28, 113, 2002.

7. ZRNČIĆ S., ORAIĆ D., ĆALETA M., MIHALJEVIĆ Ž., ZANELLA D., BILANDŽIĆ, N. Biomonitoring of heavy metals in fish from the Danube River. Environmental Monitoring and Assessment, 185, 1189, 2013.

8. LI Y., LIU H., ZHO H., MA W., HAN Q., DIAO X., XUE Q. Concentration distribution and potential health risk of heavy metals in Mactra veneriformis from Bohai Bay, China. Marine pollution bulletin 15, 97, 2015.

9. JAISHANKAR M., TSETEN T., ANBALAGAN N., MATHEW B.B., BEEREGOWDA K.N. Toxicity, mechanism and health effects of some heavy metals. Interdisciplinary Toxicology 7, 60, 2014.

10. CID B.P., BÓIA C., POMBO L., REBELO E. Determination of trace metals in fish species of the Ria de Aveiro (Portugal) 
by electrothermal atomic absorption spectrometry. Food Chemistry 75, 93, 2001.

11. OLANIRAN A.O., NAICKER K., PILLAY B. Assessment of physico-chemical qualities and heavy metal concentrations of Umgeni and Umdloti Rivers in Durban, South Africa. Environmental Monitoring and Assessment 186, 2629, 2014.

12. MOODLEY K., PILLAY S. Spatiotemporal characterization of water chemistry and pollution sources of the Umhlatuzana, Umbilo and Amanzimnyama River catchments of Durban, KwaZulu-Natal, South Africa. Environmental Earth Sciences 1273, 2015.

13. VASEEM H., BANERJEE T.K. Contamination of Metals in Different Tissues of Rohu (Labeo rohita, Cyprinidae) Collected from the Indian River Ganga. Bulletin of Environmental Contamination and Toxicology 91, 36, 2013.

14. ELNABRIS K.J., MUZYED S.K., EL-ASHGAR N.M. Heavy metal concentrations in some commercially important fishes and their contribution to heavy metals exposure in palestinian people of Gaza Strip (Palestine). Journal of the Association of Arab Universities for Basic and Applied Sciences, 13, 44, 2013.

15. WALPOLE S., PRIETO-MERINO D., EDWARDS P., CLELAND J., STEVENS G., ROBERTS I. The weight of nations: an estimation of adult human biomass. BMC Public Health 12, 439, 2012.

16. BAARS A.J., THEELEN R.M.C., JANSSEN P.J.C.M., HESSE J.M., VAN APELDOORN M.E., MEIJERINK M.C.M., ZEILMAKER M. J. Re-evaluation of humantoxicological maximum permissible risk levels. RIVM report 711701025 . Bilthoven, The Netherlands. 2001.

17. RAHMAN M.S., MOLLA A.H., SAHA N., RAHMAN A. Study on heavy metals levels and its risk assessment in some edible fishes from Bangshi River, Savar, Dhaka, Bangladesh. Food Chemistry 134, 1847, 2012.

18. IQBAL A., TABINDA A., YASAR A., MAHFOOZ Y. Heavy Metal Uptake and Toxicity in Tissues of Commercially Important Freshwater Fish (Labeo rohita and Wallago attu) from the Indus River, Pakistan. Polish Journal of Environmental studies. 26, 627, 2017.

19. MILOSKOVIC A., SIMIC V. Arsenic and other trace elements in five edible fish species in relation to fish size and weight and potential health risks for human consumption. Polish Journal of Environmental studies. 24, 199, 2015.

20. AKAN J., MOHMOUD S. Bioaccumulation of Some Heavy Metals in Fish Samples from River Benue in Vinikilang, Adamawa State, Nigeria. American Journal of Analytical chemistry 3, 727. 2012.

21. ALAM L., A.B.D., RAHIM MOHAMED C., BIN MOKHTAR M. Accumulation pattern of heavy metals in marine organisms collected from a coal burning power plant area of Malacca Strait. ScienceAsia 38, 331, 2012.

22. EL-MOSELHY K.M., OTHMA A.I., ABD EL-AZEM H., EL-METWALLY M.E.A. Bioaccumulation of heavy metals in some tissues of fish in the Red Sea, Egypt. Egyptian Journal of Basic and Applied Sciences 1, 97, 2014.

23. JAKIMSKA A., KONIECZKA P., SKÓRA K., NAMIEŚNIK J. Bioaccumulation of metals in tissues of marine animals, part II: Metal concentrations in animal tissues. Polish Journal of Environmental Studies. 20, 1127, 2011.

24. BOYD R.S. Heavy Metal Pollutants and Chemical Ecology Exploring New Frontiers. Journal of Chemical Ecology 36, 46, 2010.

25. JARUP L. Hazards of heavy metal contamination. British Medical Bulletin, 68, 167, 2003.

26. MARTIN S., GRISWOLD W. Human Health Effects of Heavy Metals. Environmental Science and Technology Breifs for Citizens. 15, 2009.

27. DWAF. Water Quality Guidelines, Aquatic Ecosystem Use. Department of Water Affairs and Forestry. 7, 1996.

28. APHA. Standard Methods for the Examination of Water and Wastewater. $20^{\text {th }}$ edn. American Public Health Association. Washington DC 2001.

29. CANLI M., ATLI G. The relationships between heavy metal $(\mathrm{Cd}, \mathrm{Cr}, \mathrm{Cu}, \mathrm{Fe}, \mathrm{Pb}, \mathrm{Zn})$ levels and the size of six Mediterranean fish species. Environmental Pollution 121, 129, 2003

30. GU Y., LIN Q., HUANG H., WANG L., NING J., DU F. Heavy metals in fish tissues / stomach contents in four marine wild commercially valuable fish species from the western continental shelf of South China Sea. Marine Pollution Bulletin. 114, 112, 2017. 